Article

\title{
European Borage (Borago officinalis L.) Yield and Profitability under Different Irrigation Systems
}

\author{
Ali Reza Seifzadeh ${ }^{1}\left(\mathbb{D}\right.$, Mohammad Reza Khaledian ${ }^{1,2}{ }^{*}$, Mohsen Zavareh ${ }^{3}$, \\ Parisha Shahinrokhsar ${ }^{4}$ and Christos A. Damalas ${ }^{5}$ (D) \\ 1 Department of Water Engineering, Faculty of Agricultural Science, University of Guilan, \\ Rasht 41635-1314, Iran; ali.seifzadeh69@yahoo.com \\ 2 Department of Water Engineering and Environment, Caspian Sea Basin Research Center, \\ University of Guilan, Rasht 41635-3756, Iran \\ 3 Department of Agronomy \& Plant Breeding, Faculty of Agricultural Science, University of Guilan, \\ Rasht 41635-1314, Iran; mzavareh@guilan.ac.ir \\ 4 Agricultural Engineering Research Department, Guilan Agricultural and Natural Resources Research and \\ Education Center, AREEO, Rasht 41635-3394, Iran; pshahinrokhsar@yahoo.com \\ 5 Department of Agricultural Development, Democritus University of Thrace, GR-68200 Orestiada, Greece; \\ cdamalas@agro.duth.gr \\ * Correspondence: khaledian@guilan.ac.ir; Tel.: +98-91-1248-1285; Fax: +98-13-1669-0281
}

Received: 8 March 2020; Accepted: 17 April 2020; Published: 20 April 2020

check for updates

\begin{abstract}
European borage (Borago officinalis L.) is a cultivated medicinal plant in Iran, but common agronomic practices about profitable cultivation are mostly unknown. A 2-yr field experiment (2013 and 2014) was conducted in Guilan Province of northern Iran to evaluate European borage yield and profitability under irrigation with surface and drip irrigation systems. Treatments included (i) rainfed production (I0, control), (ii) single irrigation (I1) applied with surface irrigation alone and drip irrigation alone, and (iii) two irrigations (I2) applied with surface irrigation alone and drip irrigation alone. In 2013, I1 increased flower dry weight by $41.0 \%$ and seed weight by $7.1 \%$ compared with rainfed European borage, while with I2, the increases in those traits were $23.4 \%$ and $0.6 \%$, respectively. In 2014, I1 increased flower dry weight by $78.0 \%$ and seed weight by $21.3 \%$ compared with rainfed European borage, while the respective increases were $51.8 \%$ and $17.3 \%$ with I2. On average, drip irrigation provided higher flower dry weight and seed weight by $39.3 \%$ and $12.6 \%$, respectively, compared with surface irrigation. Drip irrigation increased variable costs by $165.2 \%$ compared with surface irrigation but resulted in increased gross income by $23.2 \%$. Partial budgeting showed that I1 with drip irrigation provided the maximum net profit in both years. Based on the final rate of return, investing in the treatment I1 with drip irrigation was better than investing in the other treatments. Moreover, I1 with drip irrigation showed the highest value of economic water productivity and could be considered for improving the net income of European borage farmers.
\end{abstract}

Keywords: basin irrigation; drip irrigation; medicinal plant; net income; yield

\section{Introduction}

In areas with arid or semi-arid conditions like Iran, the protection and management of water resources is an important aspect contributing to sustainable development. The lack of agricultural water is a major restriction in crop production around the globe [1]. Therefore, using advanced irrigation methods, such as drip irrigation, reduces excessive consumption of water and can increase crop productivity and available cultivated land area [2]. In Guilan Province of Iran, water resources are not seriously limited, thanks to rainy weather in most periods of the year. However, fulfilling agricultural water demands is challenging owing to the construction of dams on the upstream parts of 
rivers crossing the province [3]. Therefore, the use of modern irrigation systems is required to achieve high water productivity (WP), i.e., crop yield per $\mathrm{m}^{3}$ of water consumption. With modern irrigation systems, water can be distributed more uniformly, particularly in land with irregular topography, a fact that can improve management and save of agricultural water.

The increasing use of medicinal herbs for traditional medicine products highlights the key role of these plants in the world economy [4]. These plants are precious natural resources in Iran, which can play a major role in rural development and the public health of the country. Major opportunities for the production of medicinal plants will occur in Iran if a sufficient amount of agronomic knowledge is provided. Cultivation of medicinal plants can provide significant financial returns to farmers in Iran. Most land in Guilan Province is cultivated or covered with various medicinal plants, especially in mountainous areas and sloping lands. However, in case of necessity (i.e., drought conditions), irrigation may be required to improve the productivity (crop yield per ha) of those crops and raise farmers' income. However, research data on the effect of irrigation on yield and profitability of most medicinal plants are lacking in the formal literature. By using modern methods of irrigation with a fixed volume of water, significant savings in water consumption occur, while with a lesser amount of water than surface irrigation, higher productivity can be achieved [5]. Despite the high initial investment costs, pressurized irrigation methods can be recommended due to improved crop productivity [6]. For example, drip irrigation is a major advance in irrigation systems, which could help in coping with the water shortage in agriculture [6]. Thus, the adoption of drip irrigation gains momentum in recent years in the study area owing to its ability to support productivity in many crops, while saving water.

European borage (Borago officinalis L.), a species of the Boraginaceae family, is a native herb of the Mediterranean region [7]. The whole plant is rough with white, stiff, prickly hairs. Tender leaves can be consumed raw or cooked like spinach, albeit this use is popular mainly from plants cultivated in home gardens. The flowers are bright blue and star-shaped, with prominent black anthers, forming a cone. The fruit contains four brownish-black nutlets. European borage is cultivated around the world but is native to Europe, Asia Minor, and North Africa, where can be found abundantly. The main producers are the UK, Canada, and New Zealand [8]. European borage is cultivated for medicinal and culinary uses, but today cultivation also aims to oil production [9]. The agricultural production area of this herb is not well-defined. Varieties with blue flowers are the most common, while there are varieties with white flowers, mainly oriented to culinary uses [8]. Leaves and flowers of European borage contain several chemical constituents, such as mucilage, tannin, saponins, pyrrolizidine (alkaloid), vitamin C, calcium, and potassium [10]. Moreover, the production of gamma-linolenic acid is a highly valuable dietary supplement obtained from Borago officinalis seeds $[8,11,12]$. The total volume of traded borage seeds is estimated to range between 1000-2000 tonnes per year globally, with great annual variation [8]. This variation is attributed to the strong influence of the environment on seed yield, which can range from 159 to $837 \mathrm{~kg} \mathrm{ha}^{-1}$ globally [13]. However, information about common agronomic practices is scarce. Despite the increasing use of medicinal plants, there is a low volume of European borage production, while best management practices are not well-defined [12]. Sowing date and harvest date are two important factors for the success of European borage cultivation [12]. In general, early planting resulted in significantly higher biomass production, grain yield, and harvest index, while the nitrogen fertility level had no significant effect on biomass production and grain yield [11].

A review of the formal literature showed no evidence about the impact of irrigation systems on European borage yield and profitability. Driven by the expansion of cultivation of medicinal plants in Guilan Province along with insufficient knowledge about the profitability of irrigation in this area, the main objective of the study is to know if the cultivation of European borage is profitable in irrigated land because it is a crop that has great economic importance in the area. In this context, specific objectives are to (i) examine the effect of irrigation on European borage yield and (ii) explore profitable irrigation approaches for European borage cultivation in this province. To the best of our knowledge, experimental data on the above issues do not exist in the formal literature and could be of great importance for more profitable cultivation of this medicinal plant in the study area and other areas. 


\section{Materials and Methods}

\subsection{Crop Establishment and Experimental Procedures}

A field experiment over two years (2013 and 2014) was carried out at the Research Center for Agriculture and Natural Resources of Guilan Province in northern Iran $\left(49^{\circ} 34^{\prime} 35^{\prime \prime}\right.$ E and $37^{\circ} 16^{\prime} 07^{\prime \prime} \mathrm{N}$, average altitude $24 \mathrm{~m}$ above sea level). The basic soil parameters of the experimental field are shown in Tables 1 and 2. The soil showed adequate levels of some micronutrients and had good water holding capacity. The terrain was flat with no major land slope. European borage seeds (blue flower Borago officinalis variety) were manually sown in rows with row spacing $0.6 \mathrm{~m}$ and plant spacing on the row $0.3 \mathrm{~m}$, according to the common practice in the study area. Manual sowing included carefully placing multiple seeds into the soil, and then seedlings were thinned manually to $0.3 \mathrm{~m}$ (three plants per $\mathrm{m}$ of row) a week after emergence. In general, the distance between rows may depend on the particular farming operation and equipment used. The specific plant density applied in this study implies 55,555 plants per ha, which allows irrigation and manual harvesting according to the common practice in the region. The experimental field was pre-treated with irrigation twice after sowing to facilitate seed germination and seedling establishment. The cultivation did not receive any chemical fertilizers and pesticides according to the common practice of most farmers in the region.

Table 1. Soil physical properties in three sampling depths.

\begin{tabular}{cccccc}
\hline Soil Depth $\mathbf{( c m )}$ & $\boldsymbol{\rho}_{\mathbf{b}}\left(\mathbf{g ~ c m}^{-3}\right)$ & Clay (\%) & Silt (\%) & Sand (\%) & Soil Texture \\
\hline $0-20$ & 1.31 & 49 & 48 & 3 & Silty clay \\
$20-40$ & 1.57 & 53 & 44 & 3 & Silty clay \\
$40-60$ & 1.37 & 51 & 42 & 7 & Silty clay \\
\hline \multicolumn{5}{c}{$\rho_{\mathrm{b}}$ : bulk density. }
\end{tabular}

Table 2. Soil chemical parameters in three sampling depths.

\begin{tabular}{|c|c|c|c|c|c|c|c|c|}
\hline \multirow{2}{*}{ Soil Depth (cm) } & \multicolumn{3}{|c|}{ Cations (meq $\mathrm{L}^{-1}$ ) } & \multicolumn{3}{|c|}{ Anions (meq $L^{-1}$ ) } & \multirow{2}{*}{$\mathrm{pH}$} & \multirow{2}{*}{$\mathrm{EC}\left(\mathrm{dS} \mathrm{m}^{-1}\right.$} \\
\hline & $\mathrm{Mg}^{2+}$ & $\mathrm{Ca}^{2+}$ & $\mathrm{Na}^{+}$ & $\mathrm{HCO}_{3}{ }^{-}$ & $\mathrm{Cl}^{-}$ & $\mathrm{SO}_{4}{ }^{2-}$ & & \\
\hline $0-20$ & 2.50 & 8.00 & 3.50 & 4.75 & 5.00 & 4.64 & 7.18 & 1.420 \\
\hline $20-40$ & 2.25 & 6.75 & 2.10 & 5.25 & 3.75 & 3.00 & 8.47 & 0.863 \\
\hline $40-60$ & 1.25 & 5.75 & 3.40 & 4.47 & 4.25 & 2.50 & 8.17 & 0.877 \\
\hline
\end{tabular}

The trial was established in a randomized complete block design (RCBD) with three treatments, i.e., rainfed production (control), a single irrigation (applied with surface irrigation alone and with drip irrigation alone), and two irrigations (applied with surface irrigation alone and with drip irrigation alone) replicated four times. No rain protection measures were applied for the irrigation treatments. In total, there were 20 plots. Each plot covered $7.5 \mathrm{~m}^{2}$, and all plots were separated by a 1-m alley. Surface drainage between different irrigation treatments prevented lateral seepage. Each plot included four rows of European borage plants with a length of $2.5 \mathrm{~m}$. In both years, the first irrigation (133.3 $\mathrm{m}^{3} \mathrm{ha}^{-1}$ applied with surface irrigation alone and with drip irrigation alone) was applied during stem elongation stage until field capacity (FC) (determined at $0.26 \mathrm{~cm}^{3} \mathrm{~cm}^{-3}$ ) and the second irrigation $\left(266.7 \mathrm{~m}^{3} \mathrm{ha}^{-1}\right.$ applied with surface irrigation alone and with drip irrigation alone) was applied at full flowering until FC. Field capacity was determined with pressure membrane and pressure plate apparatus. The point was to compare the profitability of each irrigation system, even if the scheduling was the same for the irrigation treatments. The maximum evapotranspiration and crop coefficient were $1.35 \mathrm{~mm} \mathrm{day}^{-1}$ and 0.34 , respectively, at the flowering stage. The water volume applied was determined using a portable water volume meter (Ningbo Wasser, model no: LXC-20E-YC, Nirou-Arkan-Karoon Co, Iran). Irrigations were scheduled when soil water status fell below $50 \%$ of FC, but always before reaching the permanent wilting point (PWP) (determined at 
$0.11 \mathrm{~cm}^{3} \mathrm{~cm}^{-3}$ ). Therefore, soil water content was monitored, and irrigation was applied before soil moisture attain values lower than $0.5 x$ FC. Soil moisture was measured weekly at three points in the plot using the gravimetric method. The depth of soil sampled varied from 10 to $30 \mathrm{~cm}$ depending on the plant growth stage. Sampling was performed by an auger between plant rows. Monthly precipitation and average air temperature during the experiments are depicted in Figure 1.
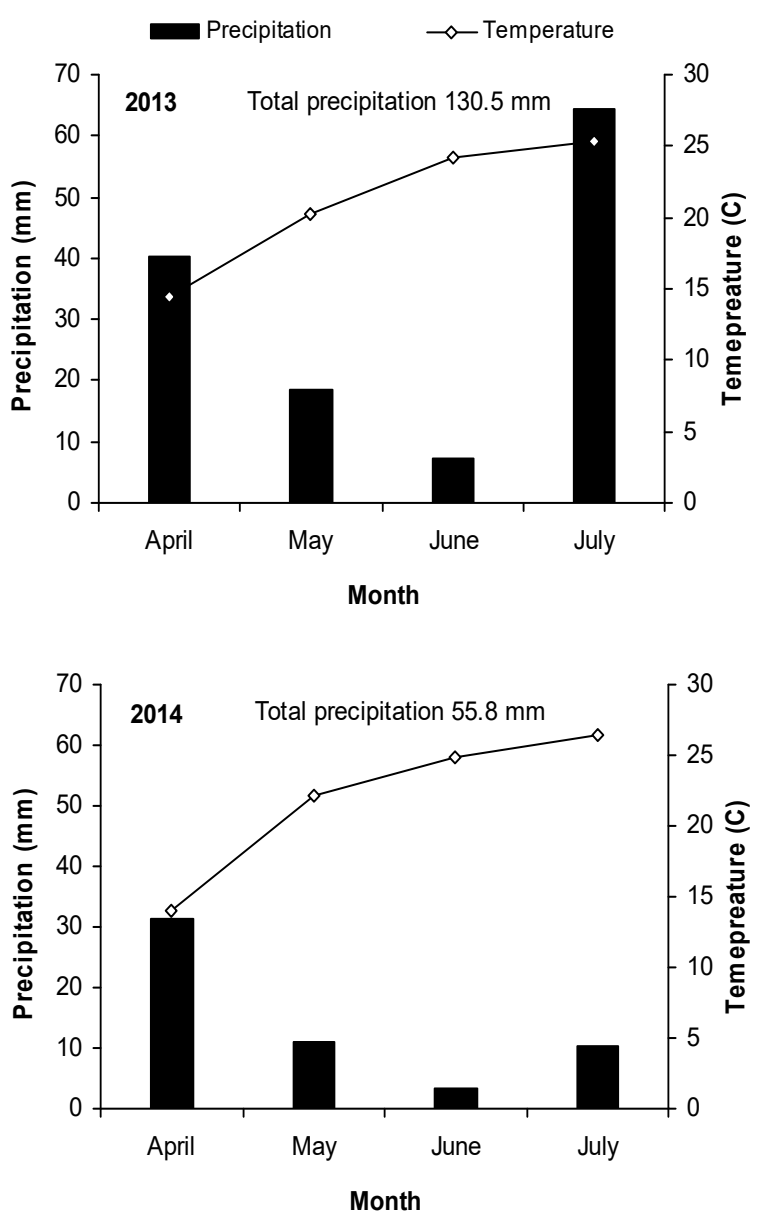

Figure 1. Monthly rainfall $(\mathrm{mm})$ and mean temperature $\left({ }^{\circ} \mathrm{C}\right)$ during each growing season.

\subsection{Samplings and Measurements}

From the beginning of flowering (on average 70 days after planting in the first year and 65 days after planting in the second year) and during flowering (on average 86 days after planting in the first year and 82 days after planting in the second year) three harvests of flowers (only blue flower petals) were done, following plant growth by daily monitoring temperature and flowering progress. Flower harvesting was done manually from two rows of the crop. The collected material was air-dried in the shade for three days to determine flower dry weight. Flower dry weight refers to the total of the three harvests. Seed harvesting was manually performed once (after 86 days after planting in the first year and after 82 days after planting in the second year), one week after the first black seeds appeared on the ground, to maximize yield due to gradual ripening of the seeds. Harvests were carried out with hand from two rows of the crop. Water productivity (WP) was defined as crop yield per $\mathrm{m}^{3}$ of water consumption, including effective rainfall for rainfed areas and diverted water from water systems for irrigated areas [14]. WP was determined by taking into account flower dry weight as well as seed weight (separately). Economic water productivity (EWP) was calculated as the ratio of the monetary value of the product to the total water use [15]. 


\subsection{Data Analysis}

Data were subjected to over year analysis, but due to significant treatment by year interaction, they were then analyzed separately for each year using a one-way analysis of variance (ANOVA) with SPSS software package. As the irrigation methods provided identical yields and there was no interaction with irrigation frequency, they were not included in the ANOVA (average values were used). Therefore, the ANOVA included three irrigation levels (rainfed production, a single irrigation (applied with surface irrigation alone and with drip irrigation alone), and two irrigations (applied with surface irrigation alone and with drip irrigation alone) and four replications. Means were examined with Duncan's test at $p<0.05$. However, because the irrigation methods differed considerably in their economic demands, they were taken into account in the economic analysis. Economic data were estimated for each experimental plot, but the average values were used for the economic analysis, based on the partial budgeting method [16], as described below.

\subsection{Economic Evaluation}

In the economic evaluation, the partial budgeting method was used in this study [16]. Various applications of this method are known, primarily assessing the profitability of management options such as irrigation and fertilizer use $[17,18]$. Partial budgeting considers the effects that small business changes have in one or more of the following areas: increase or reduction in income and increase or reduction in costs [16]. The net impact of the above effects reflects the positive financial changes subtracting the negative financial changes. The general format for a partial budget is made up of four sections: (A) additional revenues, (B) reduced costs, (C) returns foregone (or reduced revenues), and (D) extra costs (or additional costs). The change should be adopted if the sum of (A) and (B) is greater than that of the sum of (C) and (D). A schematic representation of the method is shown in Table 3.

Table 3. Partial budgeting layout comparing current situation versus alternate situation.

\begin{tabular}{cc}
\hline Benefits & Costs \\
\hline $\begin{array}{c}\text { (A) Additional revenues: revenues under the alternate } \\
\text { situation that are not received under the current situation }\end{array}$ & (C) Reduced revenues: revenues under the current situation \\
that will not be received under the alternate situation \\
$\begin{array}{cc}\text { (B) Reduced costs: costs under the current situation that will } & \text { (D) Additional costs: costs under the alternate situation that } \\
\text { be avoided under the alternate situation } & \text { are not required under the current situation } \\
\text { Total benefits: A + B } & \text { Total costs: C + D } \\
\text { NET CHANGE IN PROFIT: }(\mathrm{A}+\mathrm{B})-(\mathrm{C}+\mathrm{D})\end{array}$ \\
\hline
\end{tabular}

Partial budgeting includes any new costs associated with a proposed change, irrespective of whether these costs are fixed or variable. Therefore, this method does not distinguish between fixed and variable costs [16]. In this sense, fixed and variable costs were not applicable in our economic analysis. Fluctuations (i.e., increase and decrease) in income and cost from the substitution of each treatment by the other treatments were computed (pairwise comparisons). Thus, farm income is expected to increase due to the change, if there is a positive net, while farm income is expected to be reduced due to the change if a negative net occurs. Partial budgeting can aid extension agents in selecting practices that are the most profitable and have the best chance of being adopted by producers. Moreover, this systematic approach assists judicious decisions among farmers [16].

All farming practices were compared in terms of type and amount in different treatments. In the current study, farming practices included: (i) installation of drip irrigation system labor (four workers per ha were required for irrigated European borage with salary: USD 16 per worker), (ii) drip tape cost ( 255 rows of $65 \mathrm{~m}$ long per ha with a row spacing of $0.6 \mathrm{~m}$ required 16,575 $\mathrm{m}$ of drip tape with each meter of drip tape costing USD 0.03 with life duration of one year based on local market prices), (iii) cost of pump, connectors, etc (about USD 30), (iv) cost of filters of central control (USD 66), (v) cost of annual depreciation of filters and central control (USD 20), (vi) for the surface irrigation system for the irrigation, two workers were required per ha (salary: USD 16 per worker), (vii) in the surface irrigation 
system, three workers were required in case of fertilization use (salary: USD 16 per worker), while in the drip irrigation, fertilization labor was not calculated because in case of fertilization, fertilizers are applied through the drip irrigation system directly to the plants; furthermore, the cost of the fertilizers is the same in the two irrigation methods, (viii) because of no weeds in the field with the drip irrigation method, the herbicide cost is zero, but in the surface irrigation system, three workers per ha were required for weed control (salary: USD 16 per worker), (ix) for harvesting every $20 \mathrm{~kg}$ of the product (flowers and seed), two workers were required (salary: USD 16 per worker), and (x) water price was USD 0.03 per $\mathrm{m}^{3}$. Because no chemical agents were applied as phytosanitary treatments, no labor was calculated for phytosanitary treatments. The prices of dried flowers and seeds were considered 32 and $64 \mathrm{USD} \mathrm{kg}^{-1}$, respectively, according to local market prices in 2014. Concerning prices of dried flowers and seeds, an average of prices of several years would be more representative of income results, but due to lack of official data, the prices of the year of the study were considered. In the description of Table 7, Rows 3, 4, and 5 are fixed costs and do not change with increasing cropping area, but the other rows are variable, except for costs only for one ha. Nevertheless, the partial budgeting method does not distinguish between fixed and variable costs [16].

Treatments were arranged according to a decrease in net profit, and then pairwise comparisons based on net profit and variable costs were performed for the preferred investment analysis. Treatments with a higher net income and less variable cost than the others was considered preferable. Moreover, the rate of return on investment analysis was calculated to ascertain the priority of investment. In this regard, alterations in net income and variable costs from the substitution of a treatment were calculated, representing final variable costs and final net profit. In the case of a higher rate than the interest rate of bank deposits, the investment in that treatment with the higher net income was considered preferable to the other treatments.

\section{Results}

\subsection{Crop Yield and Water Productivity (WP)}

Although mean air temperature showed a similar trend in both growing seasons, rainfall amount and distribution differed significantly (Figure 1). The first year was rainier $(130.5 \mathrm{~mm})$ with a rainy July $(64.3 \mathrm{~mm})$, whereas the second year was drier $(55.8 \mathrm{~mm})$ with not so rainy July. In the first year, irrigation significantly improved flower dry weight, but did not affect seed weight compared with the rainfed treatment (Table 4). A single irrigation (I1) resulted in the maximum value of flower dry weight $\left(32.67 \mathrm{~kg} \mathrm{ha}^{-1}\right)$, which did not differ significantly compared with that produced with two irrigations (I2). This practically means that irrigation in the first year prevented severe drought stress during the growing season, which occurred in the rainfed treatment. WP for flower dry weight in 2013 ranged from 0.020 to $0.027 \mathrm{~kg} \mathrm{~m}^{-3}$, with I2 showing the lowest value (Table 4). WP for seed weight in 2013 ranged from 0.13 to $0.16 \mathrm{~kg} \mathrm{~m}^{-3}$, with $\mathrm{I} 2$ again showing the lowest value (Table 4).

Irrigation significantly improved flower dry weight and seed weight in the second year (Table 5). A single irrigation (I1) resulted in the maximum values of flower dry weight and seed weight (46.05 and $182.77 \mathrm{~kg} \mathrm{ha}^{-1}$, respectively), which did not differ significantly compared with those produced with two irrigations (I2; Table 5).

The slight reduction in the mentioned amounts (flower dry weight and seed weight) with I2 compared with I1 implies that much water (I2) might not be as much beneficial as adequate water (I1). Nevertheless, both I1 and I2 treatments provided higher flower dry weight and seed weight than I0. The difference between rainfed and irrigation treatments (I1 and I2) was due to the amount of rainfall in the second year, which was decreased by $84 \%$ compared to the first year. The sufficient rainfall during the first growing season led rainfed European borage to produce flower and seed yields very close to those of the irrigated European borage. WP values in 2014 were 3.1 to 6.8 times higher than those of 2013, with two irrigations (I2) showing the lowest WP values for both variables considered (Table 5). 
Table 4. European borage productivity and ANOVA results in 2013.

\begin{tabular}{|c|c|c|c|}
\hline Table & & Flower Dry Weight (kg ha-1) & Seed Weight (kg ha $\left.{ }^{-1}\right)$ \\
\hline No irrigation (I0) & & $23.17 \mathrm{~b}$ & $169.50 \mathrm{a}$ \\
\hline Single irrigation (I1) & & $32.67 \mathrm{a}$ & $181.50 \mathrm{a}$ \\
\hline Two irrigations (I2) & & $28.60 \mathrm{ab}$ & $170.50 \mathrm{a}$ \\
\hline Source of variance & df & Average of squares & Average of squares \\
\hline Block & 3 & $0.058 \mathrm{~ns}$ & $9.052 \mathrm{~ns}$ \\
\hline Treatment & 2 & $0.909 *$ & $1.773 \mathrm{~ns}$ \\
\hline Error & 6 & 0.183 & 7.462 \\
\hline Total & 11 & - & - \\
\hline \multirow[t]{2}{*}{ CV (\%) } & - & 15.21 & 15.71 \\
\hline & & $\mathrm{WP}\left(\mathrm{kg} \mathrm{m}^{-3}\right)$ & $\mathrm{WP}\left(\mathrm{kg} \mathrm{m}^{-3}\right)$ \\
\hline No irrigation (I0) & & 0.022 & 0.16 \\
\hline Single irrigation (I1) & & 0.027 & 0.15 \\
\hline Two irrigations (I2) & & 0.020 & 0.13 \\
\hline
\end{tabular}

ANOVA: analysis of variance; $\mathrm{df}$ : degrees of freedom; CV: coefficient of variation; WP: water productivity; Different letters indicate statistically significant differences; * significant at $p<0.05$; ns: non-significant.

Table 5. European borage productivity and ANOVA results in 2014.

\begin{tabular}{|c|c|c|c|}
\hline Treatment & & Flower Dry Weight $\left(\mathrm{kg} \mathrm{ha}^{-1}\right)$ & Seed Weight (kg ha $\left.{ }^{-1}\right)$ \\
\hline No irrigation (I0) & & $25.87 \mathrm{~b}$ & $150.67 \mathrm{~b}$ \\
\hline Single irrigation (I1) & & $46.05 \mathrm{a}$ & $182.77 \mathrm{a}$ \\
\hline Two irrigations (I2) & & $39.27 \mathrm{ab}$ & $176.77 \mathrm{a}$ \\
\hline Source of variance & $\mathrm{df}$ & Average of squares & Average of squares \\
\hline Block & 3 & $0.032 \mathrm{~ns}$ & $1.073 \mathrm{~ns}$ \\
\hline Treatment & 2 & $4.217^{*}$ & $116.62 *$ \\
\hline Error & 6 & 1.168 & 9.447 \\
\hline Total & 11 & - & - \\
\hline \multirow[t]{2}{*}{ CV $(\%)$} & - & 29.16 & 17.31 \\
\hline & & $\mathrm{WP}\left(\mathrm{kg} \mathrm{m}^{-3}\right)$ & $\mathrm{WP}\left(\mathrm{kg} \mathrm{m}^{-3}\right)$ \\
\hline No irrigation (I0) & & 0.15 & 0.88 \\
\hline Single irrigation (I1) & & 0.15 & 0.60 \\
\hline Two irrigations (I2) & & 0.09 & 0.40 \\
\hline
\end{tabular}

ANOVA: analysis of variance; df: degrees of freedom; CV: coefficient of variation; WP: water productivity; Different letters indicate statistically significant differences; * significant at $p<0.05 ;$ ns: non-significant.

\subsection{Economic Evaluation}

Considering yield of each treatment and the price of the product, the variation in the income resulting from the replacement of treatments was determined. The prices of European borage dried flowers and seeds were considered 32 and $64 \mathrm{USD} \mathrm{kg}^{-1}$, respectively (based on local market prices in 2014). Flower dry weight and seed weight, along with the gross income from each treatment, are shown in Table 6, while costs for each treatment are shown in Table 7. The highest gross income (3217.6 USD per ha) was calculated with a single irrigation with drip irrigation (I1S2; Table 6), which also showed the maximum total cost (797.51 USD per ha; Table 7). On average, drip irrigation showed higher gross income by $23.2 \%$ compared with surface irrigation (Table 6), while increased total cost by $165.2 \%$ compared with surface irrigation (Table 7). 
Table 6. Calculation of gross income in each treatment per ha (USD).

\begin{tabular}{ccccc}
\hline Treatment & I1S1 & I2S1 & I1S2 & I2S2 \\
\hline Yield of flower dry weight $\left(\mathrm{kg} \mathrm{ha}^{-1}\right)$ & 32.67 & 28.60 & 46.05 & 39.27 \\
Yield of seed weight $\left(\mathrm{kg} \mathrm{ha}^{-1}\right)$ & 23.37 & 22.85 & 27.25 & 24.80 \\
Gross income $\left(\$ \mathrm{ha}^{-1}\right)$ & 2541.12 & 2377.6 & 3217.6 & 2843.84 \\
\hline
\end{tabular}

I1: single irrigation; I2: two irrigations; S1: surface irrigation; S2: drip irrigation.

Table 7. Calculation of total cost for each treatment per ha (\$ US dollars).

\begin{tabular}{ccccc}
\hline Cost & I1S1 & I2S1 & I1S2 & I2S2 \\
\hline 1. Pipe installation labour & - & - & 64.00 & 64.00 \\
2. Drip tape & - & - & 497.25 & 497.25 \\
3. Cost of pump, connectors, etc. & - & - & 30.00 & 30.00 \\
4. Cost of filters or central control & - & - & 66.00 & 66.00 \\
5. Annual depreciation of filters and central control & - & - & 20.00 & 20.00 \\
6. Basin irrigation labor & 96.00 & 128.00 & - & - \\
7. Fertilization labor & 48.00 & 48.00 & - & - \\
8. Weed control labor & 48.00 & 48.00 & - & - \\
9. Harvesting labor & 89.66 & 82.32 & 117.28 & 102.51 \\
10. Water price & 2.98 & 5.96 & 2.98 & 5.96 \\
Total & 284.64 & 312.28 & 797.51 & 785.72 \\
\hline
\end{tabular}

I1: single irrigation; I2: two irrigations; S1: surface irrigation; S2: drip irrigation.

Income and cost changes from the replacement of treatments are presented in Table 8. The word "YES" in this table means that the treatment has the potential to be replaced, while the word "NO" means that the treatment does not have the potential to be replaced. I1S1 showed the potential to be replaced by I1S2, while I1S2 did not show the potential to be replaced by any other treatment. I2S1 showed the potential to be replaced by I1S1 and I1S2, while I2S2 showed the potential to be replaced by all the other irrigation treatments (Table 8).

Table 8. Possibility of replacing I1S1, I1S2, I2S1, and I2S2 treatments regarding the economical aspect.

\begin{tabular}{cccc}
\hline Alternative Treatment & Change in Income & Change in Costs & Economic Value \\
\hline For I1S1 & -163.52 & & \\
I2S1 & 676.48 & 57.64 & NO \\
I1S2 & -302.72 & 501.08 & YES \\
I2S2 & & & NO \\
For I1S2 & -676.48 & -512.87 & NO \\
I1S1 & -840.00 & -485.23 & NO \\
I2S1 & -373.76 & -11.79 & NO \\
I2S2 & & & \\
For I2S1 & 163.52 & -27.64 & YES \\
I1S1 & 840.00 & 485.23 & YES \\
I1S2 & 466.24 & 473.44 & NO \\
I2S2 & & YES \\
For I2S2 & -302.72 & -501.08 & YES \\
I1S1 & -466.24 & -473.44 & YES \\
I2S1 & 373.76 & 11.79 & \\
I1S2 & &
\end{tabular}

I1: single irrigation; I2: two irrigations; S1: surface irrigation; S2: drip irrigation.

Net profit, variable costs, and preference of treatments are shown in Table 9. Net profit is the amount of money that is left after the subtraction of total business expenses from total revenue. It is a calculation that includes almost all financial transactions in the business. Treatments dominate the 
treatment of I1S2 if they have a higher net profit. I1S2 showed the highest net profit (USD 2420.09) and dominated (Table 9).

Table 9. Analysis of plan by the priority investment method.

\begin{tabular}{cccc}
\hline Alternative Treatment & Net Profit (USD) & Cost (USD) & Domination \\
\hline I1S2 & 2420.09 & 797.51 & - \\
I1S1 & 2256.48 & 284.64 & NO \\
I2S1 & 2065.32 & 312.28 & NO \\
I2S2 & 2058.12 & 785.72 & NO \\
\hline
\end{tabular}

I1: single irrigation; I2: two irrigations; S1: surface irrigation; S2: drip irrigation.

Analysis of the final rate of return on investment was required to determine the priority of the treatment I1S2. This analysis considered the alterations in net income and variable costs from the substitution of a treatment that was calculated representing final variable costs and final net profit. According to Table 10, as the calculated final rate of return is higher than the bank interest rate, investing in the treatment I1S2 (a single irrigation with drip irrigation) is better than investing in the other treatments. Moreover, the treatment I1S2 showed the highest value of EWP (Table 10). EWP of medicinal plants is generally high due to high economic value and low water consumption.

Table 10. Analysis of the final rate of return on investment.

\begin{tabular}{|c|c|c|c|c|c|c|}
\hline Treatment & Net Profit & Variable Costs & Final Net Profit & Final Variable Costs & Final Rate of Return & $\operatorname{EWP}\left(\$ \mathrm{~m}^{-3}\right)$ \\
\hline I1S2 & 2420.09 & 797.51 & 163.61 & 512.87 & $\begin{array}{l}32 \%>\text { bank deposit } \\
\text { interest rate }\end{array}$ & 10.60 \\
\hline I1S1 & 2256.48 & 284.64 & & & & 2.12 \\
\hline I1S2 & 2420.09 & 797.51 & 354.77 & 485.23 & $\begin{array}{l}73 \%>\text { bank deposit } \\
\text { interest rate }\end{array}$ & 10.60 \\
\hline I2S1 & 2065.32 & 312.28 & & & & 1.78 \\
\hline I1S2 & 2420.09 & 797.51 & 361.97 & 11.79 & $\begin{array}{c}3070 \%>\text { bank deposit } \\
\text { interest rate }\end{array}$ & 10.60 \\
\hline I2S2 & 2058.12 & 785.72 & & & & 6.51 \\
\hline
\end{tabular}

I1: single irrigation; I2: two irrigations; S1: surface irrigation; S2: drip irrigation; EWP: economic water productivity.

\section{Discussion}

The current study assesses European borage flower yield and seed yield under different irrigation treatments and defines the most profitable irrigation method for European borage cultivation in Guilan Province, Iran. Data on the effect of irrigation are scarce for most medicinal plants, while data on the effect of irrigation on European borage productivity do not exist in the formal literature. Furthermore, an economic comparison of irrigation systems in European borage cultivation is lacking. It should be noted that borage is a dual-purpose crop in Iran conditions (flowers and seeds). However, in this study, the flower yield and the seed yield were determined in different samples. In this context, the comparison of seed yield with the seed yield in Europe (where no double purpose is made) is valid. Irrigation significantly improved flower dry weight and seed weight of European borage in both years compared with the rainfed treatment. Seed yield of European borage in our study ranged between 150 and $180 \mathrm{~kg} \mathrm{ha}^{-1}$, which seems quite low compared with data of the literature (128-650 $\mathrm{kg} \mathrm{ha}^{-1}$ using a mechanical harvest method and 570-880 $\mathrm{kg} \mathrm{ha}^{-1}$ using a hand-harvest method) [8,13]. This inconsistency can be attributed to different plant density, fertilization practices, irrigation management, and environmental conditions in each study area. The environment has a strong influence on seed yield of European borage, which has been reported to range from 159 to $837 \mathrm{~kg} \mathrm{ha}^{-1}$ [13].

Previous research with European borage showed that severe drought stress largely decreased chlorophyll and carotenoid contents of borage plants, but the application of mycorrhizal fungi alleviated the negative effects [19]. Moreover, foliar application of $400 \mathrm{ppm}$ of $\mathrm{Zn}$ and Fe, with irrigation period every three days, produced the highest values in most measured production characters (e.g., plant height, 
shoot fresh and dry matter, flower number, flower fresh and dry matter) [20]. However, experimental data on the effect of irrigation on European borage seed yield do not exist. Given the total lack of research on European borage response to irrigation, reference to other crops, even with different agronomy than European borage or even grown under different environmental conditions, is useful. For example, fennel (Foeniculum vulgare Mill) tolerated water stress, but needed appropriate amounts of water during seed germination and stem elongation stages to produce satisfactory biological yield [21]. Increasing irrigation interval decreased biomass yield of basil, while the maximum biomass yield was achieved with an irrigation interval of seven days [22]. Similarly, the biomass of black cumin (Nigella sativa L.) decreased with increasing irrigation interval [23]. However, Amiri Dehahmadi et al. [24] found that a dry phase affected the yield of dill (Anethum graveolens L.) so that reducing irrigation intervals resulted in increased seed yield. Lebaschi and Sharifi Ashourabadi [25] reported that water stress in the late growth stages increased the yield of common sage (Salvia officinalis L.). This trend has also been observed in major crops, such as sugar beet [26] and cotton [27], where moderate stress during the growing season increased the final yield because of better absorption of assimilates.

Findings concerning the abovementioned plants may not directly connect with physiology, irrigation demands, and growth of European borage, but are highly indicative of the effect of drought on crop growth and are thus very useful in view of the data lack concerning European borage. Uniform water stress of European borage plants during the growing season, as occurred under rainfed conditions of the present study, caused a decrease in all vegetative and reproductive traits and was followed by a decrease in yield levels of the plant. Water stress could lead to a decrease in the photosynthesis of oregano (Origanum vulgare L.) [28] and cumin (Cuminum cyminum L.) [29]. By contrast, water stress at the end or non-sensitive periods of plant growth led to significant savings in irrigation water, resulting in the maximum irrigation WP with a single irrigation. In addition, a single irrigation produced the maximum yield, probably due to the specific physiological characteristics (growth patterns) of European borage plants. The main reason for this finding is related with the physiology of some plants that exhibit higher yields (e.g., grain yield, fruit yield, boll weight, sugar content) when they suffer from drought stress at the end of their growth stages, with the effect depending on the time and intensity of stress. This response is connected with the fact that different crop developmental stages show different sensitivity to drought stress [30]. Moreover, osmotic adjustment is a key alternative response enabling plants under drought to maintain water absorption and cell turgor pressure, aiding a sustained photosynthetic rate and expansion growth [30]. Osmolyte accumulation in roots can give plants access to increased water reservoir by allowing root development into deeper levels of soil [31]. Nevertheless, defense mechanisms of plants against stress conditions are connected with their growth habits, and thus every claim of tolerance enhancement needs to be verified on a crop-yield basis, coupled with its economic significance from an agricultural point of view [32]. A better understanding of how long-term growth and yield are affected by water stress should aid in improving irrigation efficiency and practices, in modifying plants for more efficient water use, and in developing effective dry-land agriculture.

Concerning the economic results, I1 with drip irrigation provided the maximum net profit, taking into account the three flower harvests and one seed harvest, which are normally practiced under the conditions of the study area. Similar results have been reported in other crops, as described below. It should be emphasized that reference to other crops, as presented below, are very useful, taking into account that data on European borage irrigation are missing. For example, the economic evaluation of micro-irrigation systems in three levels of irrigation $(50 \%, 75 \%$, and $100 \%$ of crop water requirements) in cucumber (Cucumis sativus L.) showed that $75 \%$ of water requirement with the tape method was the best option [33]. Karimi et al. [34] assessed technical and economic results of drip and furrow irrigation in cotton (Gossypium hirsutum L.), where drip irrigation was found better than furrow irrigation, and $80 \%$ of water requirement in drip irrigation method had higher efficiency than the other treatments. This result is similar to those reported in potato (Solanum tuberosum L.) [35], where economical use of water by drip irrigation played a key role in managing water in crops like 
potato, indicating profitable use of drip irrigation for increasing the area of potato cultivation in India. In wheat (Triticum aestivum L.), which is an irrigated crop in the study area, the benefit to cost ratio in surface irrigation was higher than that in drip irrigation, but drip irrigation had more than double water use efficiency than surface irrigation [36]. These results showed that the drip irrigation method could be used for wheat irrigation, but the cultivation of this crop with a row seeder is not common in the region. Drip irrigation at $0.5 x$ of pan evaporation improved morphological characters and weight of fruits of red hot pepper (Capsicum annum L.), while it saved irrigation water by $58.6 \%$ over basin irrigation [37]. Dawood and Hamad [38] reported larger bean yields under drip irrigation than under furrow irrigation. The applied water with the drip irrigation was $44 \%$ of that applied with the furrow system. The adoption of optimal drip irrigation regime ( $80 \%$ of cumulative evaporation) could significantly save irrigation water over basin irrigation in "Nagpur" mandarin (Citrus reticulate Blanco) cultivation in India [39]. This option could bring more area under irrigation, resulting in higher production of citrus fruits. In cotton production, drip irrigation was found to use less water as compared with surface irrigation, providing greater WP by $0.13-0.29 \mathrm{~kg} \mathrm{~m}^{-3}$ depending on the characteristics of the various systems [40]. In addition, an investment cost of 1313-2320 euros per ha was noted for the drip irrigation systems, which was much higher than investments in equipment for surface systems [40]. Although the gross benefit:cost ratios were marginally less in drip irrigation, the use of poor-quality groundwater through drip irrigation seemed a feasible solution, especially in water-scarce areas. Considering brinjal (Solanum melongena L.) cultivation in India, the net profit achieved per mm water used was higher under drip irrigation than surface irrigation [41].

\section{Conclusions}

This study reports the technical and economic evaluation of drip irrigation and basin irrigation methods in the cultivation of European borage, for which no experimental data are available in the formal literature. Using a drip irrigation system eased off irrigation and increased yield by $29 \%$ based on flower dry weight and seed weight compared with basin irrigation system. Furthermore, based on partial budgeting and priority investment methods, it was shown that a single irrigation via drip irrigation method is pertinent to this plant in the study area and perhaps other areas with similar climatic conditions. For implementing water-saving policies and practices in the study area, technical support to farmers is necessary for assisting farmers in improving irrigation schemes, renewing infrastructure, and selecting profitable irrigation methods for sustainable European borage production because several already-suggested solutions in the study area (e.g., multiple irrigations using the basin irrigation method) might be contrary to those providing attractive economic returns to farmers. Overall, considering water shortage in semi-arid or semi-humid regions, drip irrigation as an agronomic strategy that can lead to profitable European borage production is recommended.

Author Contributions: A.R.S. conducted the study, gathered data, and analyzed data; M.R.K. conceived the idea, designed the experiments, supervised the study, interpreted data, and wrote the first draft; M.Z. analyzed data; P.S. gathered data and analyzed data; C.A.D. contributed to the literature review, data interpretation, and editing of the article. All authors have read and agreed to the published version of the manuscript.

Funding: This research received no external funding.

Conflicts of Interest: No conflict of interest is confirmed.

\section{References}

1. Elliott, J.; Deryng, D.; Müller, C.; Frieler, K.; Konzmann, M.; Gerten, D.; Glotter, M.; Flörke, M.; Wada, Y.; Best, N.; et al. Constraints and potentials of future irrigation water availability on agricultural production under climate change. Proc. Natl. Acad. Sci. USA 2014, 111, 3239-3244. [CrossRef]

2. Dagdelen, N.; Basal, H.; Yílmaz, E.; Gurbuz, T.; Akcay, S. Different drip irrigation regimes affect cotton yield, water use efficiency and fiber quality in western Turkey. Agric. Water Manag. 2009, 69, 111-120. [CrossRef]

3. Hadizadeh, F.; Allahyari, M.S.; Damalas, C.A.; Yazdani, M.R. Integrated management of agricultural water resources among paddy farmers in northern Iran. Agric. Water Manag. 2018, 200, 19-26. [CrossRef] 
4. Akbarinia, A.; Charkhchian, M.M.; Baghdadi, H.; Pilefrosh, M. Cultivation of Medicinal Plants (Borage); Publication of Saye Gostar: Tehran, Iran, 2009; p. 60.

5. Sammis, T. Comparison of sprinkler, trickle, subsurface and furrow irrigation method for row crops. Agron. J. 1980, 75, 701-704. [CrossRef]

6. Janat, M.; Somi, G. Performance of cotton crop grown under surface irrigation and drip fertigation. I. Seed cotton yield, dry matter production, and lint properties. Commun. Soil Sci. Plant Anal. 2001, 32, 3045-3061. [CrossRef]

7. Zargari, A. Medicinal Plants. Univ. Tehran Publ. 1996, 3, 511-516.

8. Galambosi, B.; Domokos, J.; Sairanen, J. Experiences with different methods of harvesting borage (Borago officinalis). Z. Für Arznei Gewürz Pflanz. 2014, 19, 61-66.

9. Asadi-Samani, M.; Bahmani, M.; Rafieian-Kopaei, M. The chemical composition, botanical characteristic and biological activities of Borago officinalis: A review. Asian Pac. J. Trop. Med. 2014, 7, S22-S28. [CrossRef]

10. Gupta, M.; Singh, S. Borago officinalis Linn, an important medicinal plant of Mediterranean region: A review. Int. J. Pharm. Sci. Rev. Res. 2010, 5, 27-34.

11. El Hafid, R.; Blade, S.F.; Hoyano, Y. Seeding date and nitrogen fertilization effects on the performance of borage (Borago officinalis L.). Ind. Crops Prod. 2002, 16, 193-199. [CrossRef]

12. Gilbertson, P.K.; Berti, M.T.; Johnson, B.L. Borage cardinal germination temperatures and seed development. Ind. Crops Prod. 2014, 59, 202-209. [CrossRef]

13. Galambosi, B.; Moilanen, T.; Angelini, L.; Pank, F.; Domokos, J.; Svoboda, P.K.; Dragland, S. Assessment of the environmental variability of a borage strain (Borago officinalis L.) by cultivation in different European regions. Sci. Bull. 2014, 10, 9-22.

14. Cai, X.; Rosegrant, M.W. World water productivity: Current situation and future options. In Water Productivity in Agriculture: Limits and Opportunities for Improvement; Kijne, J.W., Barker, R., Molden, D., Eds.; CABI: Wallingford, UK, 2003.

15. Pereira, L.S.; Cordery, I.; Iacovides, I. Improved indicators of water use performance and productivity for sustainable water conservation and saving. Agric. Water Manag. 2012, 108, 39-51. [CrossRef]

16. Tigner, R. Partial Budgeting: A Tool to Analyze Farm Business Changes; File C1-50; Iowa State University Extension and Outreach: Ames, IA, USA, 2006.

17. Arpaia, M.L.U.; Stottlemyer, D.E.; Witney, G.W. Economic analysis of irrigation and fertilization management of avocados. Hortscience 1996, 31, 156-159.

18. Donovan, C.; Wopereis, M.C.S.; Guindo, D.; Nebié, B. Soil fertility management in irrigated rice systems in the Sahel and Savanna regions of West Africa: Part II. Profitability and risk analysis. Field Crops Res. 1999, 61, 147-162. [CrossRef]

19. Rahimi, A.; Jahanbin, S.; Salehi, A.; Farajee, H. Changes in content of chlorophyll, carotenoids, phosphorus and relative water content of medicinal plant of borage (Borago officinalis L.) under the influence of mycorrhizal fungi and water stress. J. Biol. Sci. 2017, 17, 28-34.

20. Yadegari, M. Irrigation periods and $\mathrm{Fe}, \mathrm{Zn}$ foliar application on agronomic characters of Borago officinalis, Calendula officinalis, Thymus vulgaris and Alyssum desertorum. Commun. Soil Sci. Plant Anal. 2017, 48, 307-315. [CrossRef]

21. Butain, M.; Chung, B. Effects of irrigation and nitrogen on the yield components of fennel (Foeniculum vulgare Mill.). Aust. J. Exp. Agric. 1994, 34, 845-849. [CrossRef]

22. Hasani, A.; Omidbeygi, R. Effects of water stress on morphological characteristics, metabolic and psychological, in basil plant. J. Agric. Sci. 2002, 12, 47-59.

23. Norouzpour, G.; Rezvani Moghaddam, P. Effects of different irrigation and plant density on yield and yield components of medicinal plants. Iran. J. Field Crops Res. 2005, 3, 305-315.

24. Amiri Dehahmadi, R.; Rezvani Moghaddam, P.; Ehyayi, H. Effect of drought stress on some morphological characteristics and yield of herb dill, coriander and fennel in a greenhouse. Iran. J. Agric. Res. 2010, 10, 116-124.

25. Lebaschi, M.; Sharifi Ashourabadi, A. Growth of some species of medicinal plants in different conditions of water stress. J. Med. Arom. Plants Res. 2004, 20, 249-261.

26. Mirzaee, M.R.; Rezvani, S.M.A.D.; Gohari, J. The effect of water stress at different growth stages on yield and some physiological characteristics of sugar beet. In Proceedings of the Ninth Seminar of Iranian National Committee on Irrigation and Drainage, Tehran, Iran, 23-24 October 1998. 
27. Ayars, J.; Phene, C.; Hutmacher, R.; Davis, B.; Schoneman, R.; Vail, S.; Mead, R. Cotton response to non uniform and varying depths of irrigation. Agric. Water Manag. 1999, 19, 151-166. [CrossRef]

28. Said Al-Ahl, H.A.H.; Omer, E.A.; Naguib, N.Y. Effect of water stress and nitrogen fertilizer on herb and essential oil of oregano. Int. Agroph. 2009, 23, 269-275.

29. Ahmadian, A.; Tavassoli, A.; Amiri, E. The interaction effect of water stress and manure on yield components, essential oil and chemical compositions of cumin (Cuminum cyminum). Afr. J. Agric. Res. 2011, 6, 2309-2315. [CrossRef]

30. Cattivelli, L.; Rizza, F.; Badeck, F.-W.; Mazzucotelli, E.; Mastrangelo, A.M.; Francia, E.; Mare, C.; Tondelli, A.; Stanca, A.M. Drought tolerance improvement in crop plants: An integrated view from breeding to genomics. Field Crops Res. 2008, 105, 1-14. [CrossRef]

31. Serraj, R.; Sinclair, T.R. Osmolyte accumulation: Can it really help increase crop yield under drought conditions? Plant Cell Environ. 2002, 25, 333-341. [CrossRef] [PubMed]

32. Sade, N.; Vinocur, B.J.; Diber, A.; Shatil, A.; Ronen, G.; Nissan, H.; Wallach, R.; Karchi, H.; Moshelion, M. Improving plant stress tolerance and yield production: Is the tonoplast aquaporin SITIP2;2 a key to isohydric to anisohydric conversion? New Phytol. 2009, 181, 651-661. [CrossRef] [PubMed]

33. Sadrghain, S.H. Evaluated the technical and economic of microirrigation systems in three levels of irrigation in growing cucumber. J. Soil Water 2012, 26, 515-523.

34. Karimi, S.H.; Asadi, R.; Saie, M. Evaluated the technical and economic of drip and furrow irrigation systems on cotton. Iran. J. Water Res. Agric. 2014, 28, 73-83.

35. Rajeshkumar, N.K.; Raghavendra, K.; Veeresh, J.M.; Chowdareddy, M.; Chowdegowda, M.G. Evaluation of drip irrigation over conventional furrow irrigation on yield and economics of potato (Solanum tuberosum L.) crop. Int. Agric. Eng. J. 2013, 22, 15-25.

36. Torknejhad, A.; Aghaie, M.; Jafari, H.; Shirvani, R.; Roientan, R.; Nemati, A.; Shahbazi, K. Technical and economic evaluation of drip irrigation and surface irrigation in wheat. J. Res. Dev. 2006, 72, 36-44.

37. Mahajan, G.; Singh, K.G.; Sharda, R.; Siag, M. Response of red hot pepper (Capsicum annum L.) to water and nitrogen under drip and check basin method of irrigation. Asian J. Plant Sci. 2007, 6, 815-820.

38. Dawood, S.A.; Hamad, S.N. A comparison of on farm irrigation system performance. In Proceedings of the 3rd Intern Drip/Trickle Congress, Fresno, CA, USA, 18-21 November 1985; pp. 540-545.

39. Panigrahi, P.; Srivastava, A.K.; Huchche, A.D. Effects of drip irrigation regimes and basin irrigation on Nagpur mandarin agronomical and physiological performance. Agric. Water Manag. 2012, 104, $79-88$. [CrossRef]

40. Darouich, H.M.; Pedras, C.M.G.; Gonçalves, J.M.; Pereira, L.S. Drip vs. surface irrigation: A comparison focussing on water saving and economic returns using multicriteria analysis applied to cotton. Biosyst. Eng. 2014, 122, 74-90. [CrossRef]

41. Manjunatha, M.V.; Rajkumar, G.R.; Hebbara, M.; Ravishankar, G. Effect of drip and surface irrigation on yield and water-production efficiency of brinjal (Solanum melongena) in saline Vertisols. Indian J. Agric. Sci. 2004, 74, 583-587.

(C) 2020 by the authors. Licensee MDPI, Basel, Switzerland. This article is an open access article distributed under the terms and conditions of the Creative Commons Attribution (CC BY) license (http://creativecommons.org/licenses/by/4.0/). 